\title{
Implementation of Covid-19 Prevention at SDN Sugiharjo II, Tuban Regency
}

\section{Implementasi Pencegahan Covid-19 di SDN Sugiharjo II Kabupaten Tuban}

\author{
Kusuma Dwi Nur $M^{1 *}$, Nurul Ngainin² \\ Institut Agama Islam Nahdlatul Ulama Tuban, Indonesia
}

In Indonesia in 2019 in December, a disease caused by the Coronavirus SARS-COV2, which is now better known as Covid-19, emerged. Covid-19 is a type of disease that attacks the respiratory tract and is very dangerous for human life. The level of knowledge about Covid-19 is still very little, even the public still does not understand correctly about Covid- 9 so that awareness of the dangers of Covid-19 is very minimal. Meanwhile, the spread is always increasing. Covid-19 prevention must be done immediately. The IAINU Tuban tertiary institution also participates in the prevention of covid-19 transmission through one form of activity Against Covid-19 Prevention at SDN Sugiharjo II, Tuban Regency. The objectives of this research are: (1) Describing and Analyzing the Implementation Process of Prevention of Covid-19 at SDN Sugiharjo II, Tuban Regency, (2) Describing and Analyzing the Prevention of Covid19 at SDN Sugiharjo II, Tuban Regency, and (3) Describing and Analyzing the impact of Implementation on Prevention of Covid-19 at SDN Sugiharjo II, Tuban Regency.

ISSN 2579-5813 (online)

Edited by:

Moch. Bahak Udin By Arifin

Reviewed by:

Marzuki Ibrahim

${ }^{*}$ Correspondence:

Kusuma Dwi Nur M

kusumanur69@gmail.com

Received: 12 Januari 2021

Accepted: 2 Februari 2021

Published: 30 April 2021

Citation:

M Nur KD, Ngainin N, (2021)

Implementation of Covid-19

Prevention at SDN Sugiharjo II,

Tuban Regency.

Madrosatuna: Journal of Islamic

Elementary School. 5:1.

doi:

10.21070/madrosatuna.v5vi1i.1386
This study uses qualitative research types of field research (field research). Data collection techniques by means of observation, interviews and documentation. Meanwhile, the data analysis technique uses descriptive qualitative, which describes or describes in detail the data found. The technique of checking the validity of the data used the data triangulation method, peer discussion, attendance extension, and informant reviews. The results of this study indicate that: (1) The Implementation Process of Covid-19 Prevention at SDN Sugiharjo II, Tuban Regency, which goes through two processes before its implementation: First, the process before going to the field, and secondly the process of field work (implementation of the implementation of prevention of Covid-19 at SDN Sugiharjo 2). (2) The role of preventing covid-19 at SDN Sugiharjo. (3) The impact of this activity is to add insight to the public about the importance of preventing Covid-19, the community is increasingly more aware of Covid-19, and the community applies 3M (wearing masks, washing hands, and maintaining distance).

Keywords: Implementation, Humanitarian Programs, Real Work Lectures, Covid-19 Prevention

Di Indonesia pada bulan Desember 2019 lalu, muncul penyakit yang disebabkan oleh Coronavirus SARS-COV-2 yang kini lebih dikenal dengan Covid-19. Covid-19 merupakan salah satu jenis penyakit yang menyerang saluran pernafasan dan sangat berbahaya bagi kehidupan manusia. Tingkat pengetahuan tentang Covid-19 masih 
sangat sedikit, bahkan masyarakat masih kurang paham benar tentang Covid-19 sehingga kesadaran akan bahaya Covid-19 sangat minim. Sedangkan penyebarannya selalu meningkat. Pencegahan Covid-19 harus segera dilakukan. Perguruan tinggi IAINU Tuban juga turut berpartisipasi dalam pencegahan penularan Covid-19 melalui salah satu bentuk kegiatan Menentang Pencegahan Covid-19 di SDN Sugiharjo II, Kabupaten Tuban. Tujuan dari penelitian ini adalah: (1) Mendeskripsikan dan Menganalisis Proses Pelaksanaan Pencegahan Covid-19 di SDN Sugiharjo II Kabupaten Tuban, (2) Mendeskripsikan dan Menganalisis Pencegahan Covid-19 di SDN Sugiharjo II Kabupaten Tuban, dan (3) Mendeskripsikan dan Menganalisis Dampak Penerapan Pencegahan Covid-19 di SDN Sugiharjo II Kabupaten Tuban. Penelitian ini menggunakan jenis penelitian kualitatif penelitian lapangan (field research). Teknik pengumpulan data dengan cara observasi, wawancara dan dokumentasi. Sedangkan teknik analisis data menggunakan deskriptif kualitatif, yaitu mendeskripsikan atau mendeskripsikan secara rinci data yang ditemukan. Teknik pemeriksaan keabsahan data menggunakan metode triangulasi data, diskusi sejawat, penyuluhan absensi, dan review informan. Hasil penelitian ini menunjukkan bahwa: (1) Proses Pelaksanaan Pencegahan Covid-19 di SDN Sugiharjo II Kabupaten Tuban yang melalui dua proses sebelum pelaksanaannya: Pertama, proses sebelum turun ke lapangan, dan kedua proses kerja lapangan (implementasi pelaksanaan pencegahan Covid-19 di SDN Sugiharjo 2). (2) Peran pencegahan Covid-19 di SDN Sugiharjo. (3) Dampak dari kegiatan ini adalah menambah wawasan kepada masyarakat tentang pentingnya pencegahan Covid-19, masyarakat semakin sadar akan Covid-19, dan masyarakat menerapkan 3M (memakai masker, cuci tangan, dan menjaga jarak). 


\section{PENDAHULUAN}

Pada bulan Desember 2019 di Indonesia muncullah Penyakit pernapasan akut yang disebabkan oleh Coronavirus SARSCOV-2. Penyakit ini berasal dari Wuhan, provinsi Hubei di Cina yang sekarang lebih dikenal dengan Covid-19. Penyakit ini menimbulkan ancaman bagi koeksistensi sosial ekonomi global dan keberlanjutan. Banyak negara di seluruh dunia telah merespon serius terhadap pandemi covid-19. Covid-19 merupakan masalah kesehatan yang serius dan membutuhkan kerja sama serta tindakan pencegahan untuk menghentikan penyebaran virus, karena hingga kini persebaran Covid-19 meningkat semakin cepat yang melalui tetesan air liur atau keluar dari hidung ketika orang yang terinfeksi batuk atau bersin Singgih et al. (2020)

Negara diseluruh dunia telah mengambil tindakan untuk pencegahan penyebaran Covid-19, seperti menyatakan keadaan darurat, memperbaiki ketentuan medis, meminimalkan pengumpulan masal, batas penutupan (pusat rekreasi, sekolah, perpustakaan, bisnis, keanggotaan keagamaan dan olahraga), pengawasan kota yang ketat, menegakkan karantina individu, dan isolasi berskala besar. Hingga pada tingkat desa pemerintah telah mengeluarkan protokol terkait relawan desa lawan Covid-19 Kemendesa, (2020). Data covid-19 di indonesia saat ini terkonfirmasi mencapai 240,687 kasus. Di jawa timur mencapai 40372, sedangkan di daerah kabupaten tuban sendiri mencapai 475 kasus (Tuban kab, 2020).

Beberapa permasalahan yang ditemukan di SDN Sugiharjo II kabupaten Tuban yaitu : 1) kurangnya pengetahuan masyarakat terhadap Covid-19, 2) kurangnya kesadaran masyarakat terhadap protokol kesehatan, contohnya masih banyak yang tidak memakai masker, masih banyak yang mendatangi tempat kerumunan, dan lain sebagainya. Hal ini menjadi rawan akan semakin meningkatnya penyebaran Covid-19 apabila tidak ada pemahaman dan protokol kesehatan dalam penanggulangan Covid-19.

Tujuan implementasi pecegahan covid-19 yang ada di SDN Sugiharjo II Kabupaten Tuban dalam melaksanakan protokol kesehatan sesuai dengan anjuran pemerintah tentang pola hidup New Normal. Berdasarkan latar belakang di atas, peneliti ingin mengetahui lebih dalam pelaksanaan Implementasi pencegahan Covid-19 di SDN Sugiharjo II Kabupaten Tuban. Selain itu, untuk mendeskripsikan proses pelaksanaan hingga dampak adanya pelaksanaan pencegahan covid-19 tersebut. Sehingga, peneliti mengambil judul penelitian yaitu "Implementasi Terhadap Pencegahan Covid19 Di SDN Sugiharjo 2 Kabupaten Tuban”.

\section{METODE}

\section{Pendekatan Penelitian}

Menurut Sukardi berdasarkan fokus dan tujuan penelitian, maka penelitian ini merupakan kajian yang mendalam guna memperoleh data yang lengkap dan terperinci. Untuk itu penelitian ini menggunakan pendekatan deskriptif kualitatif. Penelitian deskriptif kualitatif menurut Best, seperti yang dikutip Sukardi adalah "metode penelitian yang berusaha menggambarkan dan menginterpretasikan objek sesuai dengan apa adanya" Sukardi, (2005). Demikian juga Prasetya mengungkapkan bahwa "penelitian deskriptif adalah penelitian yang menjelaskan fakta apa adanya" Prasetya, (1999).

Menurut Aminudin Penelitian kualitatif merupakan penelitian yang temuannya diperoleh berdasarkan paradigma, strategi dan implementasi model secara kualitatif Aminudin, (2016). Sedangkan menurut Manca seperti yang dikutip oleh Moleong, Penelitian kualitatif memiliki ciri-ciri sebagai berikut: (1) Merupakan tradisi Jerman yang berlandaskan idealisme, humanisme, dan kulturalisme; (2) penelitian ini dapat menghasilkan teori, mengembangkan pemahaman, dan menjelaskan realita yang kompleks; (3) Bersifat dengan pendekatan induktif-deskriptif; (4) memerlukan waktu yang panjang; (5) Datanya berupa deskripsi, dokumen, catatan lapangan, foto, dan gambar; (6) Informannya "Maximum Variety"; (7) berorientasi pada proses; (8) Penelitiannya berkonteks mikro Moleong, (1999). Oleh karena itu dalam penelitian ini berusaha mengetahui dan mendeskripsikan dengan jelas tentang "Implementasi program kemanusiaan dengan pendampingan babinsa dan bhabinkamtibmas terhadap pencegahan covid 19 di desa sugiharjo Kabupaten Tuban"

\section{Jenis Penelitian}

Suratno Arsyad Lincoln Penelitian ini jika dilihat dari lokasi sumber datanya termasuk kategori penelitian lapangan (field research). Menurut Suratno Arsyad Lincoln Penelitian lapangan adalah untuk mencari di mana peristiwa-peristiwa yang menjadi objek penelitian berlangsung, sehingga mendapatkan informasi langsung dan terbaru tentang masalah yang berkenaan, sekaligus sebagai cross checking terhadap bahan-bahan yang telah ada Suratno, (1995). Menurut Lexy J. Moleng dapat ditinjau dari segi sifat-sifat data maka termasuk dalam penelitian Kualitatif yaitu penelitian yang bermaksud untuk memahami fenomena tentang apa yang dialami oleh subjek penelitian misalnya perilaku, persepsi, motivasi, tindakan dan lain-lain secara holistik, dan dengan cara deskripsi dalam bentuk kata-kata dan bahasa, pada suatu konteks khusus yang alamiah dan dengan memanfaatkan berbagai metode alamiah Suratno, (2006).

Dalam hal ini peneliti berupaya mendeskripsikan secara mendalam bagaimana dan usaha apa saja yang dilakukan Peneliti dalam Implementasi terhadap pencegahan covid 19 di SDN Sugiharjo II Kabupaten Tuban. Bogdan dan Taylor Berpendapat studi kasus juga berusaha mendeskripsikan suatu latar, objek atau suatu peristiwa tertentu secara mendalam Bogdan et al. (1982). Pendapat ini didukung oleh Yin yang menyatakan bahwa studi kasus merupakan strategi yang dipilih untuk menjawab pertanyaan how dan why, jika fokus penelitian berusaha menela'ah fenomena kontemporer (masa kini) dalam kehidupan nyata Yin, (2002).

\section{Kehadiran Peneliti}

Dalam penelitian kualitatif peneliti sendiri atau dengan bantuan orang lain merupakan alat pengumpul data utama, hal itu dilakukan karena jika memanfaatkan alat yang bukan manusia maka sangat tidak mungkin untuk mengadakan 
penyesuaian terhadap kenyataan-kenyataan yang ada di lapangan. Selain itu hanya manusialah yang dapat berhubungan dengan informan dan yang mampu memahami kaitan kenyataan-kenyataan di lapangan Nasution, (1990). Pada penelitian ini peneliti datang langsung ke lokasi penelitian guna menggali informasi yang berkaitan dengan Implementasi terhadap pencegahan covid 19 di SDN Sugiharjo 2 Kabupaten Tuban Peneliti akan datang ke lokasi untuk melakukan penelitian di lapangan. Untuk itu, kehadiran peneliti sangat diperlukan untuk mendapatkan data yang komprehensif dan utuh.

\section{Data dan Sumber Data}

Pendapat dari W. Mantja pengambilan data dalam penelitian ini dengan cara snowball sampling yaitu informan kunci akan menunjuk orang-orang yang mengetahui masalah yang akan diteliti untuk melengkapi keterangannya dan orang-orang yang ditunjuk dan menunjuk orang lain bila keterangan kurang memadai begitu seterusnya Mantja, (2003). Peniliti melakukan obseravasi dan wawancara kepada kepala Sekolah Wahyu Sulistyowati SDN SUgiharjo II.

Menurut Nana Sudjana Ibrahim Sumber data primer adalah sumber data penelitian yang diperoleh secara langsung dari sumber asli (tidak melalui media perantara Ibrahim, (1984). Dalam penelitian ini sumber data primernya yakni sumber data yang diperoleh dan dikumpulkan langsung dari informan yang terdiri dari implementasi terhadap pencegahan covid 19 di SDN Sugiharjo II Kabupaten Tuban.

Pemilihan informan dalam penelitian kualitatif dilakukan dengan cara snowball sampling yakni informan kunci akan menunjuk orang-orang yang mengetahui masalah yang akan diteliti untuk melengkapi keterangannya dan orang-orang yang ditunjuk akan menunjuk orang lain bila keterangan yang diberikan kurang memadai begitu seterusnya, dan proses ini akan berhenti jika data yang digali diantara informan yang satu dengan yang lainnya ada kesamaan sehingga data dianggap cukup dan tidak ada yang baru. Bagi peneliti hal ini juga berguna terhadap validitas data yang dikemukakan oleh para informan.

Pendapat Marzuki mengatakan sumber data sekunder adalah sumber data penelitian yang diperoleh secara tidak langsung melalui media perantara (diperoleh dan di catat oleh pihak lain) (1991: 55). Adapun data sekunder untuk penelitian ini diambil dari buku penunjang dan data hasil observasi yang berkaitan dengan fokus penelitian. Semua data tersebut diharapkan mampu memberikan deskripsi tentang Implementasi terhadap pencegahan covid 19 di Desa Sugiharjo II Kabupaten Tuban

\section{Metode Pengumpulan Data}

Metode penelitian yang tepat, juga perlu memilih teknik dan alat pengumpulan data yang relevan. Penggunaan teknik operasional dan alat pengumpulan data yang tepat memungkinkan diperolehnya data yang objektif. Adapun teknik pengumpulan data yang digunakan dalam penelitian ini adalah:

Obervasi Partisipan. S. Margono menyampaikam observasi digunakan sebagai pengamatan dan pencatatan secara sistematik terhadap segala yang tampak pada objek penelitian (S. Margono, 2005: 159). Metode observasi pada penelitian ini digunakan untuk mengumpulkan data yang berkaitan dengan fokus penelitian. Dalam hal ini peneliti berusaha melakukan suatu pengamatan dan pencatatan secara sistematis Implementasi terhadap pencegahan covid 19 di SDN Sugiharjo II Kabupaten Tuban. Adapun dalam pelaksanaan teknik observasi pada penelitian ini adalah menggunakan observasi partisipan. Adapun tujuan dilakukannya observasi partisipan adalah untuk mengamati peristiwa sebagaimana yang terjadi di lapangan secara alamiah. Pada teknik ini, peneliti melibatkan diri atau berinteraksi secara langsung pada kegiatan yang dilakukan oleh subjek dengan mengumpulkan data secara sistematis dari data yang diperlukan.

Wawancara Mendalam. Sumber data yang sangat penting dalam penelitian kualitatif ialah berupa manusia yang dalam posisi sebagai narasumber atau informan. Untuk mengumpulkan informasi dari sumber data ini diperlukan teknik wawancara (Lexy J. Moleng, 2006: 117). Peneliti juga mengadakan wawancara mendalam adalah percakapan antara dua orang dengan maksud tertentu dalam hal ini antara peneliti dengan informan, di mana percakapan yang di maksud tidak sekedar menjawab pertanyaan dan mengetes hipotesis yang menilai sebagai istilah percakapan dalam pengertian seharihari, melainkan suatu percakapan yang mendalam untuk mendalami pengalaman dan makna dari pengalaman tersebut. Awal bertemu kepala Sekolah: Wahyu Sulistyowati kita melakukan wawacara dan observasi terkait implementasi terhadap pencegahan covid-19 di Desa Sugiharjo kabupaten tuban.

Pada waktu melakukan wawancara tidak terstruktur, pertanyaan-pertanyaan dilakukan secara bebas (free interview) pada pertanyaan-pertanyaan umum tentang kegiatan kecerdasan ganda dan sebagainya. Pada pertanyaanpertanyaan umum tentang eksistensi program kemanusiaan dengan pendampingan babinsa dan bhabinkamtibmas terhadap pencegahan covid 19 di desa sugiharjo Kabupaten Tuban. Selanjutnya dilakukan wawancara terfokus (focused interview) yang pertanyaannya tidak memiliki struktur tertentu, akan tetapi selalu berpusat pada satu pokok yang lainnya. Dalam hal ini fokus diarahkan pada Implementasi program kemanusiaan dengan pendampingan babinsa dan bhabinkamtibmas terhadap pencegahan covid 19 di desa sugiharjo Kabupaten Tuban, Dengan kata lain, wawancara pada tahap kedua ini tidak menggunakan instrument terstruktur namun peneliti telah membuat garis-garis yang disusun berdasarkan fokus penelitian. Kedua metode ini dilakukan secara terbuka (open interview) sesuai dengan sifat penelitian kualitatif yang open ended, dan ditujukan kepada informan-informan yang dianggap sebagai informan kunci (key informant) yaitu pencegahan covid 19 yaitu di SDN Sugiharjo II Kabupaten Tuban.

Dokumentasi. Suharsimi Arikunto menyampaikan metode dokumentasi adalah metode yang digunakan untuk mencari data mengenai hal-hal atau variabel-variabel yang berupa catatan, transkrip, buku, surat kabar, agenda atau lain sebagainya Arikunto, (2006). Pada sebuah penelitian, teknik dokumentasi digunakan sebagai sumber data pendukung. Di samping itu data dokumentasi diperlukan untuk melengkapi data yang diperoleh dari wawancara dan observasi. Peneliti 
dalam hal ini menggunakan teknik dokumentasi untuk memperoleh data yang berupa arsip-arsip, catatan-catatan, buku-buku yang berkaitan implementasi terhadap pencegahan covid 19 di SDN Sugiharjo II Kabupaten Tuban. Dokumen yang di maksud bisa berupa foto-foto, dokumen sekolah, transkrip wawancara, dan dukumen tentang sejarah sekolah serta perkembangnya, ke semua dokumentasi ini akan dikumpulkan untuk di analisis demi kelengkapan data penelitian. Dalam hal ini peneliti mengambil foto-foto yang berkaitan terhadap pencegahan covid 19 di SDN Sugiharjo II Kabupaten Tuban.

\section{Teknik Analisi Data}

Menurut Miles dan Huberman dalam penelitian ini peneliti menggunakan analisis deskriptif dengan menerangkan proses berfikir induktif yaitu berangkat dari faktor- faktor khusus, peristiwa-peristiwa yang konkrit kemudian dari faktor-faktor atau peristiwa yang khusus dan konkrit kemudian itu ditarik generalisasi yang bersifat umum Miles et al. (1984). Adapun teknik analisis data yang akan dilakukan peneliti yaitu :

Reduksi Data. Data yang diperoleh di lapangan sebelum dilakukan laporan lengkap dan terperinci disortir dulu, yaitu yang memenuhi fokus penelitian. Dalam mereduksi data, semua data lapangan ditulis sekaligus dianalisis, direduksi, dirangkum, dipilih hal-hal yang pokok, difokuskan pada halhal yang penting, dicari tema da polanya, sehingga disusun secara sistematis dan lebih mudah dikendalikan.

Penyajian Data. Dalam penelitian ini peneliti akan menyajikan data dalam bentuk laporan berupa uraian yang lengkap dan terperinci. Ini dilakukan peneliti agar data yang diperoleh dapat dikuasai dengan dipilah secara fisik dan dipilah kemudian dibuat dalam kertas dan bagan.

Menarik Kesimpulan. Dalam penelitian ini, setelah dilakukan verifikasi maka akan ditarik kesimpulan yang merupakan hasil dari penelitian ini. Yaitu dengan cara mencari makna fokus penelitian. Peneliti melakukan verifikasi dan menarik kesimpulan guna mencari makna yang terkandung di dalamnya. Pada awalnya kesimpulan yang dibuat bersifat tentatif, kabur, dan penuh keraguan, tetapi dengan bertambahnya data dan pembuatan kesimpulan demi kesimpulan akan ditemukan data yang dibutuhkan. Ibrahim Bafadal menyatakan berikut adalah "model interaktif" yang digambarkan oleh Miles dan Huberman, seperti yang dikutip Bafadal, (2012)

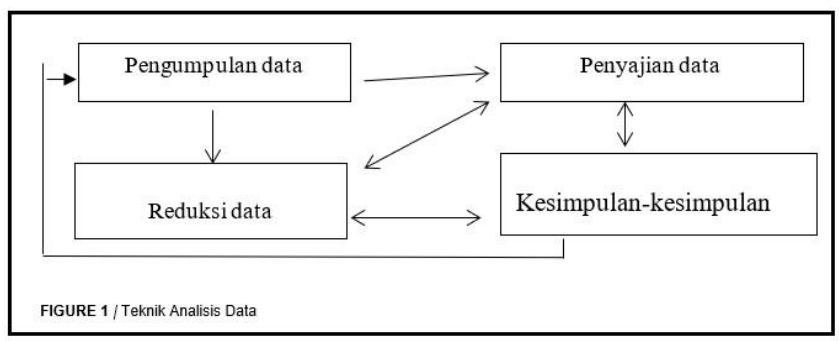

Proses Sebelum Terjun Ke Lapangan. Penentuan fokus penelitian dan penyesuaian teori. Pada proses pertama ini, peneliti belum melaksanakan kegiatan penelitian yang berupa program kemanusiaan terhadap pencegahan covid-19 atau kegiatan lainnya. Peneliti hanya menentukan fokus penelitian dan penyesuaian materi. Hal ini dilakukan dengan bertujuan untuk membatasi objek penelitian agar peneliti mampu memilih dan membedakan banyaknya data yang ada di lapangan sesuai dengan data yang diperlukan. Sehingga data yang diperoleh relevan dengan data yang cari peneliti.

Dalam menentukan fokus penelitian ini, peneliti menyesuaikan dengan tingkat kebaruan informasi dan keadaan atau kondisi lingkungan saat ini yaitu keadaan lingkungan masyarakat yang sekarang berada pada masa pandemi covid-19. Dimana masa pandemi ini menyebabkan banyaknya masyarakat yang terpapar dan meninggal karena covid-19. Hal ini, sesuai dengan yang dikatakan (Tiyas. N, 2020: 2) bahwa, "Angka kasus masyarakat dunia yang terpapar dan meninggal karena covid terus mengalami peningkatan, yang membuat WHO bergerak cepat mengarahkan dan menghimbau seluruh Negara untuk menyusun kebijakan publik terutama kebijakan protokol kesehatan bagi warga negaranya".

Dengan demikian, perlu adanya pencegahan covid-19 agar menurunkan angka kasus masyarakat yang meningkat yaitu salah satunya dengan melaksanakan program kemanusiaan. Fokus penelitian yang ditentukan peneliti dalam melaksanakan penelitian atau sebelum melaksanaan program kemanusiaan yaitu difokuskan pada proses pelaksanan pencegahan covid-19 di SDN Sugiharjo II Tuban. Jadi, penentuan fokus penelitian sangat penting sekali karena akan terlihat pada judul atau topik penelitian yang kemudian dipergunakan sebagai acuan peneliti merumuskan masalah. Setelah menentukan fokus penelitian, peneliti tidak lupa dalam melakukan penyesuaian dengan teori yang berasal dari berbagai referensi terpercaya.

Pelaksanaan Observasi. Proses kedua yang dilakukan setelah peneliti menentukan focus penelitian dan menyesuaikan dengan teori atau sebelum pelaksanaan kegiatan program kemanusiaan yaitu peneliti melakukan observasi terlebih dahulu di SDN Sugiharjo II kabupaten Tuban. Observasi dilakukan pada bulan November dengan bertujuan untuk mengetahui keadaan dan kondisi yang ada di desa Sugiharjo.

\section{HASIL DAN PEMBAHASAN}

Selain itu, observasi juga dapat digunakan untuk mengumpulan data atau informasi terkait dengan kegiatan pelaksanaan mencegah covid-19. Seperti : peneliti melakukan pengamatan terhadap siswa terkait pelaksanaan protokol kesehatan (penggunaan masker dan handsanitizer), wawasan siswa mengenai covid-19, dan terkait mengenai bagaimana kewaspadaan siswa terhadap covid-19. Pelaksanaan observasi sangat membantu peneliti dalam menemukan berbagai keadaan dan kondisi SDN Sugiharjo II Kabupaten Tuban. Pembuatan surat izin penelitian.

Surat izin penelitian dibuat untuk diserahkan kepada Kepala SDN Sugiharjo II Kabupaten Tuban, dengan tujuan agar Kepala SDN memberikan izin terkait dengan pelaksanaan penelitian kegiatan program kemanusiaan terhadap pencegahan covid-19 yang dilaksanakan pada SDN Sugiharjo II Kabupaten Tuban. Sosialisasi tersebut dilakukan melalui beberapa metode salah satunya yaitu kampanye 
kesehatan dengan melakukan pesan kepada siswa SDN Sugiharjo II Kabupaten Tuban agar selalu mematuhi protokol kesehatan untuk mencegah penyebaran covid-19, diantaranya selalu cuci tangan secara rutin menggunakan sabun dan air yang mengalir, selalu menggunakan masker jika keluar rumah dan selalu jaga jarak aman dengan orang yang batuk atau bersin, tidak menyentuh mulut atau hidung dan mata, selalu tutup mulut atau hidung saat batuk atau bersin dengan lengan atau tisu, dan yang terakhir jangan keluar rumah bila merasa tidak enak badan.

Kegiatan yang ketiga yaitu pembagian hand sanitizer kepada siswa di SDN Sugiharjo Kabupaten Tuban. Hand sanitizer adalah cairan atau gel yang umumnya digunakan untuk mengurangi patogen pada tangan. Hand sanitizer menjadi produk yang efektif untuk menggantikan mencuci tangan dengan sabun, terlebih ketika berada di tempat umum dan transportasi umum. Hal ini sesuai dengan pernyataan Nerissa Erviana Fardani dalam artikelnya yang memaparkan beberapa manfaat dari penggunaan hand sanitizer yairu menjaga kebersihan tangan dan mencegah bakteri yang ada pada tangan, dapat digunakan pada benda lain seperti membersihkan benda mati (leptop, pegangan pintu dan sebagainya) dan fleksibel mudah dibawa kemana saja serta mudah di simpan (Nerissa Erviana Fardani, 2020). Handsanitizer yang kami buat ini diaplikasikan pada SDN Sugiharjo II Kabupaten Tuban.

Pada kegiatan penelitian, kami membagikan 100 Masker di SDN Sugiharjo Kabupaten Tuban, Masker di bagikan pada siswa yang masih belum mematuhi protokol kesehatan. Program penyemprotan cairan desinfektan yang dilaksankan pada jam 14.00 WIB- Selesai ini sangat sederhana yakni menggunakan bahan rumah tangga diantaranya cairan pemutih dan pembersih lantai yang dicampur dengan air. Jadi pada kegiatan ini, tidak hanya melakukan penyemprotan tetapi juga membuat racikan disinfektan. Kami mengutamakan bahan disinfektan yang akan digunakan agar tidak berdampak negatif bagi lingkungan serta tetap mematuhi protokol kesehatan upaya pecegahan covid-19 dan sesuai dengan ketentuan yang sudah ditetapkan WHO. Penyemprotan yang dilakukan selama sekitar dua jam ini dilakukan dengan menggunakan satu tangki yang disemprotkan oleh para peneliti. Selama penyemprotan berlangsung, kami mendapatkan respon baik dari SDN Sugiharjo II Kabupaten Tuban dan belum mengalami kendala.

Sebelum dilaksanakan penyemprotan, kami melakukan koordinasi dan survei bersama pihak desa untuk rute penyemprotannya. Dengan adanya kegiatan penyemprotan disinfektan, harapan kami dapat mengurangi pasien yang terpapar covid-19 selama pandemi. Selain itu, digunakan untuk mengantisipasi penyebaran virus covid-19 dan membantu siswa SDN Sugiharjo II Kabupaten Tuban untuk tetap tenang dan waspada dalam menghadapi pandemi secara bersama-sama. Hal ini, sesuai dengan hasil penelitian yang dilakukan oleh Fiza, (2020) bahwa : Poster dan stiker yang ditempelkan berupa informasi tentang protokol kesehatan bagi siswa dan himbauan dalam rangka pencegahan dan pengendalian covid-19 serta langkah yang benar dalam membiasakan cuci tangan dengan sabun dan air mengalir. Tentu saja kegiatan Implementasi Terhadap pencegahaan covid-19 ini bertujuan untuk mengedukasi, menginformasikan, dan mengingatkan kembali protokolprotokol kesehatan di era Covid-19 guna mengurangi penyebaran covid-19 di Kota Tuban.

Peran Terhadap Pencegahan Covid-19 Di SDN Sugiharjo II Kabupaten Tuban. a. Edukasi pengetahuan siswa terkait covid-19 berupa pengertian covid-19, gejala covid-19, pencegahan covid-19, alat pelindung diri dari covid-19. b. Penerapan 3M (Memakai masker, mencuci tangan dan menjaga jarak), c. Edukasi dengan membuat video terkait pecegahan covid seperti mencuci tangan dengan baik dan benar, membuat masker kain tanpa mesin, membuat cairan handsanitizer dan cairan disinfektan dan cara serta tips menangani stress selama dirumah dengan mengunjungi dokter dan psikolog terdekat. bertujuan untuk mengedukasi, menginformasikan, dan mengingatkan kembali protokolprotokol kesehatan di era Covid-19 guna mengurangi penyebaran covid-19 di Kota Tuban. Melakukan pengawasan fasilitas atau prasarana dalam pelaksanaan Terhadap Pencegahan Covid-19 Di SDN Sugiharjo II Kabupaten Tuban. Dengan adanya sosialisasi dan pengawasaan pada siswa SDN Sugiharjo Kabupaten Tuban tetap melakukan 3 M (Masker, Mencuci Tangan dan Menjaga Jarak) dengan adanya fasilitas. Tersediannya Masker: a) Penyemprotan Disinfektan; b) Praktek Pembuatan HandSanitizer dan Pembagian Pada siswa SDN Sugiharjo II Kabupaten Tuban.

Menjaga Pencegahan Covid-19 Di SDN Sugiharjo II Kabupaten Tuban. Terhadap Pencegahan Covid-19 Di SDN Sugiharjo II Kabupaten Tuban yaitu a. Memberikan informasi kepada seluruh siswa di SDN SugiharjoII terkait pencegahaan covid-19 itu sendiri harus terlaksana dengan baik, b. Melaksanakan sosialisasi terkait pencegahaan covid-19 yang c. Penerapan maupun pelaksanaan untuk mematuhi segala anjuran yang sudah diinformasikan, disosialisasikan oleh peniliti kepada siswa di SDN Sugiharjo Kabupaten Tuban dapat terlaksana dengan baik serta benar sesuai anjuran dari pemerintah. Dampak Implementasi Terhadap Pencegahan Covid-19 Di SDN Sugiharjo II Kabupaten Tuban. Pelaksanaan terhadap pencegahan covid-19 di SDN Sugiharjo II Kabupaten Tuban memiliki dampak yang positif bagi siswa SDN Sugiharjo Tuban Kabupaten Tuban. Dampak positif tersebut, sangat membantu pemerintah dalam menangani penyebaran covid-19. Berikut deskripsi dampak dari pelaksanaan Implementasi Pencegahan Covid-19 di SDN Sugiharjo II Kabupaten Tuban:

Menambah wawasan kepada siswa tentang pentingnya mencegah covid-19. Pelaksanaan kegiatan dalam menambah wawasan kepada siswa tentang pentingnya mencegah covid19 yaitu melalui sosialisasi kepada siswa di SDN Sugiharjo II Kabupaten Tuban. Sosialisasi tersebut berupa informasi pencegahaan covid-19, bahayanya covid-19 terhadap kesehatan manusia kepada siswa SDN Sugiharjo II Kabupaten Tuban dan sekaligus membagikan masker kepada siswa SDN Sugiharjo II Kabupaten Tuban. Kegiatan kedua, yaitu dengan adanya pembuatan handsanitezer yang kemudian dibagikan kepada siswa SDN Sugiharjo II Kabupaten Tuban. Dalam membagikan handsanitezer, peneliti memberikan beberapa edukasi mengenai pengertian covid-19, gejala covid-19, pencegahan covid-19, alat pelindung diri dari covid-19 dan cara mencuci tangan dengan benar dalam mencegah covid-19. 
Karena dengan adanya pemberian edukasi pengetahuan masyarakat terkait covid-19 akan menambah antusias dan wawasan seputar covid-19 sebagai bekal pengetahuan pencegahan covid-19. Hal ini, sesuai dengan hasil penelitian yang dilakukan oleh Haryani, (2020), Kegiatan yang ketiga, yaitu penyemprotan disinfektan di kantor yang ada di SDN Sugiharjo II Kabupaten Tuban. Penyemprotan dilakukan dengan menggunakan satu tengki yang berisi campuran air, cairan pemutih dan pembersih lantai.

Menambah kewaspadaan siswa terhadap covid-19. Dengan adanya kegiatan sosialisasi, membagikan masker dan hansanitezer serta adanya anjuran $3 \mathrm{M}$, warga siswa semakin lebih waspada terhadap covid-19 yaitu dengan mematuhi, menjalankan dan melaksanakan dengan baik anjuran $3 \mathrm{M}$ yang dianjurkan oleh pemerintah dalam mencegah penularan covid-19. Anjuran $3 \mathrm{M}$ tersebut yaitu memakai masker, mencuci tangan dengan alur yang benar, dan menjaga jarak dengan adanya pemberlakuan pembatasan kegiatan masyarakat (PPKM) yang sekarang berlaku. Hal ini dibuktikan dengan banyaknya siswa yang sudah mematuhi protokol kesehatan, selalu memakai masker ketika keluar rumah ataupun pergi ke sekolah dan dalam pembelajaran di sekolah. Siswa menerapkan 3M dan pemberlakuaan pembatasaan kegiatan masyarakat (PPKM), Setelah menambahnya wawasan siswa terhadap pencegahan covid19 dan adanya sikap lebih waspada membuat siswa selalu menggunakan masker jika bepergian, selalu mencuci tangan sesuai dengan alur yang benar, menjaga jarak dengan tidak mengadakan kegiatan yang sifatnya mengumpulkan orang.

\section{KESIMPULAN}

Proses Implementasi Terhadap Pencegahan Covid-19 Di Desa Sugiharjo Kabupaten Tuban yaitu melalui dua proses sebelum pelaksanaannya : Pertama, proses sebelum terjun ke lapangan (mulai dari penentuan fokus penelitian dan penyesuaian teori, pelaksanaan observasi, pembuatan surat ijin penelitian dari kampus untuk Kepala Sekolah SDN Sugiharjo II Kabupaten 2 Tuban), dan proses kedua yaitu proses pekerjaan lapangan (pelaksanaan Implementasi Pencegahaan Covid-19 di SDN Suhiharjo II Kabupaten Tuban). Peran Terhadap Pencegahan Covid-19 Di Desa Sugiharjo Kabupaten Tuban yaitu memberikan pembinaan territorial, melakukan pengawasan fasilitas atau prasarana dalam pelaksanaannya, dan berperan menjaga keamanan dan ketertiban siswa selama pelaksanaan Terhadap Pencegahan Covid-19 Di SDN Sugiharjo II Kabupaten Tuban berlangsung. Implementasi Terhadap Pencegahan Covid-19 Di Desa Sugiharjo Kabupaten Tuban memiliki dampak yang positif bagi masyarakat, yaitu : pertama, menambah wawasan kepada masyarakat tentang pentingnya mencegah covid-19 melalui sosialisasi pencegahaan covid-19, pembagian masker, pembuatan handitaizer, dan penyemprotan disinfektan dan kantor yang ada di SDN Sugiharjo II Kabupaten Tuban. Kedua, Siswa semakin lebih waspada terhadap covid-19 seperti mematuhi protokol kesehatan, menjalankan dan melaksanakan dengan baik dan benar. Keempat, Siswa berusaha selalu menerapkan 3M dan pemberlakuaan pembatasaan kegiatan masyarakat (PPKM) seperti memakai masker, mencuci tangan dengan alur yang benar, dan menjaga jarak dengan adanya dengan Pemberlakuan Pembatasan Kegiatan Masyarakat (PPKM) yang sekarang berlaku.

\section{REFRENCES}

Adi Nugroho, Teguh. 2017. Peran Bintara Pembina Desa (Babinsa) Dalam Pembinaan Teritorial Dan Penanaman Nilai Bela Negara Di Desa Babadan Kecamatan Kaliori Kabupaten Rembang. Jurusan Politik Dan Kewarganegaraan Fakultas Ilmu Sosial Universitas Negeri Semarang.

Alkitab. 2013. Lembaga Alkitab Indonesia (Anggota IKAPI). Jakarta.

Aminudin. Tujuan, Strategi dan Model dalam Penelitian Kualitatif,(dalam Metodologi Penelitian Kualitatif : Tinjauan Teoritis dan Praktis). Malang : Lembaga Penelitian UNISMA.

Amirudin. 2004. Pengantar Metode Penelitian Hukum. Jakarta : Raja Grafindo Persadam.

Arikunto, Suharsimi. 1988. Penilaian Program Pendidikan. Jakarta : PT Bina Aksara.

Azhari, C. A. 2018. Strategi Mengenal Khalayak Bhabinkamtibmas (Bhayangkara Pembinaan Keamanaan dan Ketertiban Masyarakat) Polsekta Samarinda Utara dalam Membangun Kemitraan dengan Masyarakat di Kelurahan Mugirejo. E-Journal Ilmu Komunikasi, 6(1).

Bafadal Ibrahim, Teknik Analisis Data Penelitian Kualitatif, (dalam Metodologi Penelitian Kualitatif : Tinjauan Teoritis dan Praktis), (Malang : Lembaga Penelitian UNISMA, tt)

Dwi Archika, Nazwa. Coronavirus Disease 2019. Pendidikan Jasmani Olahraga Kesehatan SMA Negeri 3 Medan Tahun Ajaran 2019/2020.

Fiza Ishlahiyya Churaez, dkk. 2020. Pembuatan Dan Penyemprotan Disinfektan : Kegiatan Kkn Edisi Covid-19 Di Desa Bringin, Malang. Volume 2, Nomor 2, Juni 2020 e-ISSN : 2656-4661.

Hamalik, Oemar. 2007. Dasar-dasar Pengembangan Kurikulum. Bandung : PT Remaja Rosdakarya.

Hesti Kartikasari \& Kengkin Dita. 2017. Implementasi Nilai-Nilai Persatuan Dan Kemanusiaan Dalam Tradisi Sambatan Di Desa Karangan Kecamatan Jumantono Kabupaten Karanganyar. (Studi Kasus Di Desa Karangan Kecamatan Jumantono). Program Studi Pendidikan Pancasila Dan Kewarganegaraan Fakultas Keguruan Dan Ilmu Pendidikan Universitas Muhammadiyah Surakarta.

https://sugiharjo.desa.id/first. Statistik Covid 19. Pukul 12:29. Tanggal 15 Nopember 2020.2020

https://tubankab.go.id/page/informasi-tentang-virus-corona-covid-19. Persebaran Covid-19. Pukul 18:00. Tangal publish Data 21 Oktober 2020.

https://www.kemkes.go.id/article/view/20031700001/Dokumen-Resmi-danProtokol Penanganan-COVID-19.html. Pukul 15:41. Tanggal 15 Nopember 2020.

Huberman A.M. Miles M.B. 1984. Qualitative Data Analysis. Beverly Hills, California : Sage Publication Inc.

Ibrahim, Sudjana Nana. 1984. Penelitian dan Penilaian Pendidikan. Bandung : Sinar Baru.

Ignatius Kristanto. 2020. Paparan Topik Virus Corona atau Penyakit Covid-19. https://kompaspedia.kompas.id/baca/paparan-topik/penyakit-covid-19. Pukul10:50. tanggal 15 Nopember 2020.

Lincoln, Arsyad Suratno. 1995. Metodologi Penelitian Untuk Ekonomi dan Bisnis. Yogyakarta : UPP AMPYKPN.

Conflict of Interest Statement: The authors declare that the research was conducted in the absence of any commercial or financial relationships that could be construed as a potential conflict of interest.

Copyright (C) 2020 M Nur and Ngainin. This is an open-access article distributed under the terms of the Creative Commons Attribution License (CC BY). The use, distribution or reproduction in other forums is permitted, provided the origi- nal author(s) and the copyright owner(s) are credited and that the original publication in this journal is cited, in accordance with accepted academic practice. No use, distribution or reproduction is permitted which does not comply with these terms 